\title{
Jerzy Tomaszewski o własnej drodze badawczej, nauczycielach i kolegach historykach
}

\author{
Jerzy Tomaszewski on His Research, Mentors, \\ and Fellow Historians
}

The central part of the article is the account of Jerzy Tomaszewski (1930-2014), a Warsaw historian of economic history, the history of Central Europe of the $20^{\text {th }}$ century, and a pioneer of research on the history of Polish Jews. Tomaszewski gave an account of his research career. In an essential part of the conversation, he recalls his teachers: Profs. Witold Kula and Andrzej Grodek. The conversation also sheds light on the Stalinization of historical science in the first half of the 1950s. Tomaszewski also pointed to the main inspirations and conditions that made him undertake his research. An interesting and little-known thread is Tomaszewski's cooperation with historians from other Central European countries, including Czechoslovakia, as well as the recollections of the PRL (Polish People's Republic) restrictions of the freedom of scientific research. The conversation is preceded by a short biography of Jerzy Tomaszewski and a note discussing the origins of this source material.

Keywords: Jerzy Tomaszewski (1930-2014), economic history, history of Polish Jews Słowa kluczowe: Jerzy Tomaszewski (1930-2014), historia gospodarcza, historia Żydów polskich

\section{Rys biograficzny}

Jerzy Tomaszewski należał do tych badaczy XX w., którzy swoim dorobkiem wzbogacili polską historiografię na kilku bardzo różnych obszarach. Uprawiane przez niego pola badawcze były bardzo rozmaite: interesowały go sprawy gospodarcze, kraje Europy Środkowej i Wschodniej, regiony pograniczne, mniejszości narodowe, tematyka żydowska. Przez sześć dziesięcioleci pracy naukowej opublikował około tysiąca pozycji. Biografia in-

1 Pełne zestawienie bibliografii Jerzego Tomaszewskiego za lata 1953-2000 można znaleźć można znaleźć w księdze jubileuszowej profesora. Zob. Bibliografia Jerzego Tomaszewskiego za lata 1953-2000, [w:] Rozdziaf wspólnej historii. Studia z dziejów Żydów w Polsce ofiarowane Jerzemu Tomaszewskiemu w siedemdziesiątą 
telektualna Tomaszewskiego czeka na swojego autora, który zechce odtworzyć koleje jego losów i przeanalizować całość jego twórczości. Kompetentnego omówienia jego życiorysu dokonali Szymon Rudnicki i Artur Markowski². Po śmierci historyka ukazały się także nekrologi, w których przypomniano ważniejsze fakty z jego życia i dorobku³. Dokonano także osobnego omówienia dorobku Tomaszewskiego w zakresie historii Żydów polskich ${ }^{4}$. W niniejszym szkicu ograniczam się jedynie do podstawowych informacji biograficznych i bibliograficznych, mających na celu ułatwienie lektury rozmowy z historykiem.

Jerzy Tomaszewski urodził się 8 października 1930 r. w Radomsku. Miejsce urodzenia nie czyni go jednak Radomszczaninem - miejscowość była jednym z wielu miejsc, w których pracował jego ojciec, Dionizy Tomaszewski, zatrudniony w Powszechnym Zakładzie Ubezpieczeń Wzajemnych. Rodzina powróciła do Warszawy w 1938 r. i tu przyszły historyk poszedł do szkoły powszechnej. Także w Warszawie przeżył lata II wojny światowej5.

Początek kariery naukowej Tomaszewskiego wypada na 1954 r., kiedy obronił pracę magisterską w Szkole Głównej Planowania i Statystyki. Promotorem jego pracy był Stanisław Rączkowski, jednak uczonymi, którzy wywarli największy wpływ na przyszłego profesora byli historycy: Andrzej Grodek i Witold Kula. Również w SGPiS w 1960 r. obronił pracę doktorską i cztery lata później się habilitował. Pracował w wielu instytucjach naukowych. W latach 1954-1956 był aspirantem w Instytucie Nauk Społecznych przy KC PZPR ${ }^{6}$ (Tomaszewski był członkiem PZPR od 1949 r., jednak w 1981 r. opuścił szeregi partii). Po rozwiązaniu tej placówki powrócił do SGPiS, gdzie doktoryzował się w 1960 r. na podstawie rozprawy Polityka stabilizacyjna Władysława Grabskiego ${ }^{7}$ napisanej pod kierunkiem Witolda Kuli. Pozytywne recenzje pracy napisali Henryk Jabłoński i Jerzy Jurkiewicz. Rok później praca ukazała się drukiem ${ }^{8}$. W 1963 r. został docentem na podstawie rozprawy habilitacyjnej Z dziejów Polesia 1921-1939. W 1969 r. rozpoczął pracę na Uniwersytecie Warszawskim, z którym związany był do końca życia. Do 1990 r. pracował na Wydziale Dziennikarstwa i Nauk Politycznych w Instytucie Nauk Politycznych, gdzie w 1972 r. został mianowany profesorem nadzwyczajnym, a w 1980 r. - zwyczajnym ${ }^{10}$. W 1990 r. przeniósł się do Instytutu Historycznego, gdzie współtworzył Centrum Badania i Nauczania Dziejów

rocznicę urodzin, red. J. Żyndul, Warszawa 2001, s. 15-70. Kontynuację zawiera następna księga, zob. Bibliografia prac prof. Jerzego Tomaszewskiego za lata 2000-2009, [w:] Narody i polityka. Studia ofiarowane profesorowi Jerzemu Tomaszewskiemu, red. A. Grabski, A. Markowski, Warszawa 2010, s. 13-30.

2 A. Markowski, S. Rudnicki, Jerzy Tomaszewski (1930-2014), [w:] J. Tomaszewski, Żydzi w II Rzeczypospolitej, oprac. A. Markowski, S. Rudnicki, Warszawa 2016, s. 413-427.

3 J. Żyndul, Jerzy Tomaszewski - in memoriam, „Kwartalnik Historii Żydów” 2015, z. 1, s. 187-190; A. LandauCzajka, Jerzy Tomaszewski (8 X 1930 - 4 XI 2014), „Kwartalnik Historyczny” 2015, z. 1, s. 216-219; A. Markowski, Prof. Jerzy Tomaszewski (1930-2014), „Dzieje Najnowsze” 2015, z. 2, s. 239-241.

4 K. Zieliński, Jerzego Tomaszewskiego wkład w badania nad historią Żydów Polskich, [w:] J. Tomaszewski, Żydzi w II Rzeczypospolitej, s. 429-441.

5 Wojenne doświadczenia Jerzy Tomaszewski opisał w osobnym wspomnieniu, gdzie także sporo miejsca poświęcił genealogii rodziny: zob. J. Tomaszewski, Odpowiedzi na niektóre pytania zadane lub niezadane, jak też na rozmaite domysły lub wymysły, życzliwe, a także miej lub bardziej nieżyczliwe, lub zrodzone z bezinteresownej ciekawości, „Midrasz" 2013, z. 5, s. 54-66.

6 Archiwum Akt Nowych [AAN], Archiwum Szkół Partyjnych, Akta Aspiranckie Jerzego Tomaszewskiego, sygn. 97/272.

7 AAN, Ministerstwo Edukacji Narodowej, Akta Jerzego Tomaszewskiego, Odpis dyplomu doktorskiego, sygn. 15193, k. 78

8 Zob. J. Tomaszewski, Stabilizacja waluty w Polsce. Z badań nad polityką gospodarczą rządku polskiego przed przewrotem majowym, Warszawa 1961.

9 Zob. idem, Z dziejów Polesia 1921-1939. Zarys stosunków społeczno-ekonomicznych, Warszawa 1963.

10 Archiwum Uniwersytetu Warszawskiego, Akta Jerzego Tomaszewskiego, sygn. K-26176. 
i Kultury Żydów w Polsce im. Mordechaja Anielewicza, którym kierował do 2001 r. Od 1968 r. związany był również z Żydowskim Instytutem Historycznym im. Emanuela Ringelbluma jako członek Rady Naukowej. Wchodził również w skład Kolegium Redakcyjnego oraz Rady Redakcyjnej wydawanego przez ŻıH „Kwartalnika Historii Żydów” (w latach 1950-2000 „Biuletynu Żydowskiego Instytutu Historycznego”). Był również członkiem redakcji ukazującego się od 1986 r. w Oksfordzie rocznika „Polin. Studies in Polish Jewry”.

Był uczonym o niezwykle szerokim horyzoncie badawczym. Przez wiele lat zajmował się dziejami ekonomicznymi Polski w okresie dwudziestolecia międzywojennego. Obok monografii poświęconych szczegółowym zagadnieniom z tego zakresu był autorem - najczęściej wespół ze Zbigniewem Landauem - wielu prac syntetycznych i przekrojowych. Swego rodzaju podręcznikiem jest napisany przez nich Zarys historii gospodarczej Polski 1918-1939, wydany w 1960 r. ${ }^{11}$ Praca ta doczekała się sześciu wydań, zmienianych i uzupełnianych, z których ostatnie ukazało się w 1999 r. Na szczególną uwagę zasługuje też synteza poświęcona temu zagadnieniu - czterotomowe dzieło Gospodarka Polski międzywojennej 1918-193912. Kolejne tomy ukazywały się przez ponad 20 lat: pierwszy, w 1967 r., ostatni zaś w 1989 r. Zainteresowania Tomaszewskiego gospodarką nie ograniczały się jednak wyłącznie do Polski i wyłącznie do okresu II Rzeczypospolitej. Był, wraz Jerzym Ciepielewskim, Ireną Kostrowicką i Zbigniewem Landauem, współtwórcą podręcznika Historia gospodarcza świata XIX i XX wieku, wydanego w 1970 r. ${ }^{13}$ Wybór dyscypliny, jaką były dzieje gospodarcze, nie był wyjątkowy dla pokolenia do którego należał Tomaszewski. Historycy, których początek kariery przypadał na okres stalinowski, w historii gospodarczej znajdowali drogę ucieczki od doktrynerstwa i zwulgaryzowanego marksizmu. Bardzo często po kilkunastu latach zmieniali pola badawcze, zwracając się ku dziejom kultury czy historii społecznej. Tomaszewski nigdy jednak nie odszedł od historii gospodarczej, za to rozszerzał obszar swoich zainteresowań o kolejne dyscypliny i tematy.

Jedną z najważniejszych dziedzin badań Jerzego Tomaszewskiego była historia krajów Europy Środkowej w XX w., z których najwięcej miejsca poświęcił Czechosłowacji, następnie Czechom i Słowacji oraz Bułgarii ${ }^{14}$. Jest między innymi autorem pracy, która stanowi syntetyczne ujęcie dziejów Czech i Słowacji ${ }^{15}$ w XX w. W roku śmierci historyka ukazała się synteza dziejów dwudziestowiecznych Czech ${ }^{16}$.

Zagadnieniem, które Jerzy Tomaszewski uprawiał z niezwykle dużym powodzeniem, była problematyka mniejszości narodowych w Polsce. Niemal równolegle, w 1985 r., ukazały się dwie prace poświęcone tej tematyce. Pierwsza to Rzeczpospolita wielu narodów ${ }^{17}$, druga - Ojczyzna nie tylko Polaków ${ }^{18}$. Sześć lat później opublikował również niewielką

11 Z. Landau, J. Tomaszewski, Zarys historii gospodarczej Polski 1918-1939, Warszawa 1960.

12 lidem, W dobie inflacji 1918-1923, Warszawa 1967; iidem, Od Grabskiego do Piłsudskiego: okres kryzysu poinflacyjnego i ożywienia koniunktury 1924-1929, Warszawa 1971; iidem, Wielki kryzys 1930-1935, Warszawa 1982; iidem, Lata interwencjonalizmu państwowego 1936-1939, Warszawa 1989.

13 J. Ciepielewski, I. Kostrowicka, Z. Landau, J. Tomaszewski, Historia gospodarcza świata XIX i XX wieku, Warszawa 1970.

14 J. Tomaszewski, Rozwój Bułgarii w latach 1944-1956, Warszawa 1980; idem, Butgaria 1944-1971. Trudna droga do socjalizmu, Warszawa 1989.

15 Idem, Czechy i Słowacja, Warszawa 2006.

16 Idem, Republika Czeska 1918-2013, Warszawa 2014.

17 Idem, Rzeczypospolita wielu narodów, Warszawa 1985.

18 Idem, Ojczyzna nie tylko Polaków. Mniejszości narodowe w Polsce w latach 1918-1939, Warszawa 1985. 
książeczkę Mniejszości narodowe w Polsce XX wieku ${ }^{19}$. Wielu szczegółowym problemom z tej dziedziny poświęcił osobne studia, które ukazywały się w różnych czasopismach naukowych. Aktywność dziejopisarska na tym właśnie polu przyniosła mu w pewnych kręgach opinię historyka kontrowersyjnego. W 1984 r. burzę wywołał opublikowany na łamach pisma „Nurt” wywiad z Tomaszewskim, w którym oskarżył żołnierzy 27 Dywizji Wołyńskiej Piechoty Armii Krajowej o mordowanie ludności ukraińskiej20.

Jednym z najistotniejszych obszarów badawczych Jerzego Tomaszewskiego pozostawała jednak historia Żydów polskich. Od lat sześćdziesiątych publikował w "Biuletynie ŻlH”. Pierwsze teksty z tej dziedziny dotyczyły aspektów gospodarczych. W późniejszych latach jego badania zaczęły się rozszerzać na inne problemy. Do najważniejszych publikacji z tego zakresu należą: Zarys dziejów Żydów w Polsce w latach 1918-1939²1, wydany w 1990 r., oraz praca Preludium Zagłady. Wygnanie Żydów polskich z Niemiec w 1938 roku², wydana w 1998 r. Obok tego opublikował wiele monografii i artykułów z tej tematyki²3. Bardzo ważne są tu również artykuły przeglądowe oraz publikacje popularnonaukowe. Warto zwrócić uwagę na te mniejsze formy, zwłaszcza na recenzje i polemiki. Wśród nich znajdziemy interesujące artykuły, w których Tomaszewski poddawał krytyce publikacje o charakterze antysemickim.

Tomaszewski był również współautorem obszernej syntezy dziejów Europy, która ukazała się 1997 r. pod redakcją Antoniego Mączaka²4. W 2001 r. opublikował napisane wraz z Andrzejem Chojnowskim przekrojowe opracowanie dziejów Izraela w XX w. ${ }^{25}$ Był także współtwórcą Muzeum Historii Żydów Polskich „Polin” otwartego 26 października 2014 r.

W ciągu sześćdziesięciu lat pracy naukowej Jerzy Tomaszewski wypromował dwudziestu dziewięciu doktorów: historyków i politologów. Do grona jego uczniów należą m.in. Anna Magierska, Jan Kofman, Wojciech Materski, Janusz Radziejowski, Adam Koseski, Marek Jabłonowski, Natalia Aleksiun, Artur Markowski i August Grabski²6.

Odsyłając Czytelników do bardziej szczegółowych, wymienionych już życiorysów Jerzego Tomaszewskiego, a także czekając na pogłębione studium biograficzne historyka, warto zwrócić uwagę na jeden jeszcze wątek, który łatwo umyka lapidarnym ujęciom, a mianowicie sposób funkcjonowania Tomaszewskiego w środowisku naukowym w warunkach PRL. Przytoczymy dwa epizody. Pierwszy rozgrywał się na przestrzeni lat siedemdziesiątych. Badaczka dziejów najnowszych Maria Turlejska (1918-2004) w 1972 r. opublikowała pracę Zapis pierwszej dekady ${ }^{27}$ będącą omówieniem zmian politycznych w pierwszym dziesięcioleciu po II wojnie światowej. Książka jednak została szybko wycofana z dystrybucji, autorkę zwolniono z pracy w Wojskowej Akademii Politycznej im. Feliksa Dzierżyńskiego, a w czasopismach ukazały się negatywne recenzje autorstwa partyjnych historyków ${ }^{28}$. Jerzy Toma-

19 J. Tomaszewski, Mniejszości narodowe w Polsce XX wieku, Warszawa 1991.

20 Mity i fakty. Z prof. Jerzym Tomaszewskim na temat Kresów Wschodnich w latach 1918-1939-rozmawia Piotr Łuczka, „Nurt” 1984, z. 4, s. 4-6; z. 5, s. 8-11.

21 J. Tomaszewski, Zarys dziejów Żydów w Polsce w latach 1918-1939, Warszawa 1990.

22 Idem, Preludium Zagłady. Wygnanie Żydów polskich z Niemiec w 1938 roku, Warszawa 1998.

23 Już po śmierci Tomaszewskiego ukazał się książkowy wybór jego mniejszych studiów z tematyki żydowskiej: zob. J. Tomaszewski, Żydzi w II Rzeczypospolitej, Warszawa 2016.

24 Historia Europy, red. A. Mączak, Wrocław 1997.

25 A. Chojnowski, J. Tomaszewski, Izrael, Warszawa 2001.

26 Prace doktorskie promowane przez prof. Jerzego Tomaszewskiego, [w:] Narody i polityka, s. 41-44.

27 Zob. M. Turlejska, Zapis pierwszej dekady 1945-1954, Warszawa 1972.

28 A. Koseski, W. Ważniewski, recenzja: M. Turlejska, Zapis..., „Z Pola Walki” 1973, z. 2-3, s. 359-365. 
szewski był jedynym, który odpowiedział na jedną z takich recenzji, wysyłając swoją replikę do kwartalnika „Z Pola Walki”. Redakcja nie zdecydowała się na jej opublikowanie. Historyk nie przeszedł jednak nad tą sprawą do porządku dziennego, domagając się konsekwentnie publikacji i jego tekst po ośmiu latach został w końcu opublikowany ${ }^{29}$.

Drugi epizod warty przypomnienia miał miejsce w 1985 r.. Wówczas z pracy w Instytucie Historii Polskiej Akademii Nauk zwolniono - z powodów politycznych - Bronisława Geremka (1932-2008). Tomaszewski wystosował list do prezesa PAN kwestionujący tę decyzję: „Byłoby [...] niedobrze, gdyby pewnego dnia ktoś stwierdził, że Polska Akademia Nauk zdołała się pozbawić najbardziej doświadczonych uczonych, ponieważ jej kierownictwu nie odpowiadały ich poglądy polityczne." - pisał w liście, postulując przyjęcie Geremka do pracy ${ }^{30}$. Przytoczone sytuacje (podobnych było więcej) świadczą o odwadze cywilnej historyka, którym kierowało poczucie sprawiedliwości i życzliwość.

Za swoją działalność naukową był wielokrotnie nagradzany. Dwukrotnie (wraz ze Zbigniewem Landauem) odbierał nagrodę „Polityki”: w 1971 r. za pracę Robotnicy przemysłowi w Polsce ${ }^{31}$, a następnie w 1985 r. za książkę Monachium 1938². W 1998 r.otrzymał Nagrodę Jana Karskiego i Poli Nireńskiej.

Jerzy Tomaszewski zmarł 4 listopada 2014 r. w Warszawie. Spoczął na Cmentarzu Wojskowym na Powązkach.

\section{(Osobista) historia rozmowy}

Pomysł przeprowadzenia wywiadu z Jerzym Tomaszewskim narodził się spontanicznie. 18 czerwca 2010 r. w murach Pałacu Kazimierzowskiego odbywała się uroczystość nadania wybitnemu znawcy spraw żydowskich, Antony'emu Polonsky'emu, doktoratu honoris causa Uniwersytetu Warszawskiego. Tomaszewski wystąpił tam w roli promotora. Po uroczystości zostałem przedstawiony profesorowi i nie minęło więcej niż kilka minut, gdy zaproponowałem dłuższą, rejestrowaną rozmowę.

Miesiąc później, 20 lipca, spotkaliśmy się w Instytucie Historycznym UW. Dość szybko porzuciłem przygotowaną wcześniej listę pytań. Wywiad zamienił się w autentyczną rozmowę, trwającą blisko trzy godziny. Jedyne, o co starałem się dbać, to zachowanie pewnej chronologii. Głównym tematem relacji złożonej przez Tomaszewskiego były warunki uprawiania historii gospodarczej, Europy Środkowej oraz historii mniejszości, w tym dziejów Żydów polskich w PRL. Wielokrotnie jednak mój rozmówca przekroczył wstępnie założone ramy. Co warto podkreślić: nie było moją ambicją ani nie czułem się dość kompetentny, by zebrać całościową relację o życiu i doświadczeniach profesora, czyli przeprowadzić z nim „wywiad-rzekę”. Po kilku dniach przesłałem Tomaszewskiemu zredagowany tekst do autoryzacji. Sam usunąłem kilka fragmentów, które były komentarzem do moich opinii, a które zdarzyło mi się podczas tej rozmowy wyrazić. Profesor

29 J. Tomaszewski, List do redakcji, „Z Pola Walki” 1981, z. 2, s. 261-264.

30 Kopia listu skierowana do dyrektora IH PAN znajdująca się w teczce kadrowej Bronisława Geremka; Archiwum Instytutu Historii Polskiej Akademii Nauk, sygn. 2/691.

31 Z. Landau, J. Tomaszewski, Robotnicy przemysłowi w Polsce. Materialne warunki bytu 1918-1939, Warszawa 1971.

32 lidem, Monachium 1938. Polskie dokumenty dyplomatyczne, Warszawa 1985. 
na etapie autoryzacji, poza bardzo drobnymi poprawkami natury technicznej, usunął kilka niewielkich fragmentów, w których przytaczał nazwiska naukowców prezentujących w marcu 1968 r. postawę antysemicką, przywołując zasadę „o zmarłych dobrze albo wcale". W tym miejscu - mimo naukowego charakteru tekstu - nie mogę nie pozwolić sobie na podzielenie się z własnymi odczuciami. To, że w mojej głowie zrodził się pomysł na przeprowadzenie tej rozmowy, a także to, że jej przebieg był tak interesujący, wynikało z niespotykanej osobowości profesora. Od pierwszej chwili wyczuwało się jego autentyczną szlachetność, przyzwoitość i skromność. Na liczne niegodziwości, które go w życiu spotykały, odpowiadał ironicznym żartem. Przykładem tego, może być jego stosunek do przypisywanych mu - jako historykowi - licznych narodowości. „Mogę występować jako Chińczyk" - mówił, puentując w ten sposób naszą rozmowę. Był dżentelmeński w sposobie bycia i formułowania ocen.

Początkowo przeznaczyłem ten materiał do publikacji na portalu Młodsza Europa, który z inspiracji Jerzego Kłoczowskiego między 2009 a 2010 r. współtworzyłem wraz z grupą wolontariuszy przy Instytucie Europy Środkowo-Wschodniej w Lublinie. Z powodów pozamerytorycznych inicjatywa portalu zgasła dość szybko i rozmowa do dziś pozostawała nieopublikowana. Piąta rocznica śmierci profesora, która przypadła 4 listopada 2019 r., może być doskonałą okazją, by ten materiał ocalić i udostępnić szerokiemu gronu czytelników.

Rozmowa z prof. Jerzym Tomaszewskim (20 lipca 2010 r., Warszawa)

Co skłoniło Pana Profesora, by rozpocząć studia na uczelni o profilu ekonomicznym, jaką była SGPiS?

To dlatego, że jako historyk nie miałem żadnych szans. Należałem niewątpliwie do najgorszych historyków w swojej klasie. (śmiech) Ta historia była okropnie nudna. Opanowanie wszystkich wypraw Napoleona, co i gdzie robił, przy czym nie wiadomo, po co się pchał pod piramidy, przekraczało moje możliwości. I tak byłem dumny, że na jakiejś klasówce, z której zresztą dostałem dwóję, potrafiłem napisać pół strony w zeszycie. Nie miałem żadnych szans na historii, to nie ulega żadnych wątpliwości. (śmiech)

Poza tym mnie interesowała Polska międzywojenna, którą w tym czasie prawie nikt się nie zajmował. Jedynie ekonomiści, bo chyba tylko Leon Grosfeld ${ }^{33}$ opublikował istotne rzeczy. Zdawałem w dobrym towarzystwie mojego przyjaciela z gimnazjum, Zbigniewa Landaua ${ }^{34}$, który ma rodzinne tradycje ekonomistów.

\section{I jako student SGPiS postanowił się Pan Profesor zająć historią gospodarczą?}

Ja trafiłem na tę historię gospodarczą, prawdę mówiąc, dość przypadkowo. Przedmiot ten wykładał profesor Andrzej Grodek ${ }^{35}$. Jako wykładowca był trudny do słuchania z powodu niezbyt wyraźnego sposobu mówienia. Zwłaszcza, że myśmy te wykłady mieli na

33 Leon Grosfeld (1911-1987), działacz komunistyczny i historyk dziejów gospodarczych. W 1953-1953 zastępca dyrektora Instytutu Historii PAN. W latach osiemdziesiątych publikował na łamach podziemnej „Krytyki”.

34 Zbigniew Landau (1931-2018), historyk dziejów gospodarczych i ekonomista, pracownik naukowy SGPiS/SGH.

35 Andrzej Grodek (1901-1959), historyk dziejów gospodarczych, absolwent i pracownik naukowy SGH/SGPiS, rektor SGH w 1946-1949, rektor SGPiS w 1956-1959. 
wielkiej auli bez żadnego nagłośnienia i tym trudniej było słuchać. Podczas jednego z wykładów jakieś poruszone przez niego sprawy mnie zainteresowały. Podszedłem do niego z jakimś pytaniem czy komentarzem po wykładzie, a skończyło się na tym, że następnego dnia Irena Kostrowicka ${ }^{36}$ z jego Zakładu Historii Gospodarczej zapytała czy chcę zostać, jak to się wtedy nazywało, „zastępcą asystenta”. To była funkcja, którą stworzono wobec niedostatku pracowników i łapano na to, kogo można. Widocznie byłem albo jedynym, który zadał jakieś pytanie, i to pytanie miało jakiś sens, albo po prostu w ogóle nikogo nie było. W ten sposób zostałem do tego zespołu przyczepiony i właściwie nie było wiadomo na początku, co ze mną zrobić. Na początku musiałem się zająć biblioteką w tym średniej wielkości zakładzie, i tak już tam zostałem.

\section{Ale Andrzej Grodek chyba nie był jedynym mistrzem historii gospodarczej na SGPiS?}

Wkrótce były tam dwie osoby: Andrzej Grodek i Witold Kula ${ }^{37}$. Była też Irena Kostrowicka i Józef Chlebowczyk ${ }^{38}$, ale to było już młodsze pokolenie, chociaż doświadczone i starsze ode mnie. Poza nimi na uczelni byli już tylko ekonomiści i nikt więcej. W następnych latach doszli następni asystenci: mój młodszy (o prawie trzy lata) wspólnik Zbyszek Landau, Andrzej Jezierski ${ }^{39}$ (już nie żyje), Marylka Ciechocińska ${ }^{40}$ (dziś profesor na jednej z uczelni pozawarszawskich), Jurek Ciepielewski ${ }^{41}$ (już nieżyjący), przez pewien czas także Jurek Jedlicki42 $\mathrm{i}$ inni.

\section{Andrzej Grodek wydaje się dziś - chyba niesłusznie - zapomniany. Chciałbym poprosić Pana Profesora o wspomnienie o nim.}

Andrzej Grodek jako opiekun naukowy był niebezpieczny. A to dlatego, że miał pomysły. (śmiech) Kiedyś przy jakiejś okazji musiałem wystąpić w gronie paru osób, m.in. Kostrowicka i Chlebowczyk, i zreferować jakieś zagadnienie o Kołłątaju. Ponieważ byłem jeszcze nieznany, to profesor wcześniej mnie zaprosił do domu, żebym mu przedstawił, co chcę powiedzieć w moim wystąpieniu. Grodek podjął ze mną naturalnie dyskusję, i na tym polegało właśnie jego niebezpieczeństwo. Oczywiście jako człowiek oczytany i zorientowany, wiedział o problematyce i o okresie o wiele więcej niż ja, wobec tego bez

36 Irena Kostrowicka (1920-2008), historyk dziejów gospodarczych, pracownik naukowy SGPiS/SGH. W 19691975 prorektor SGPiS.

37 Witold Kula (1916-1988), historyk dziejów gospodarczych i społecznych. Absolwent UW. Pracownik naukowy Wolnej Wszechnicy Polskiej (1937-1939), Uniwersytetu Łódzkiego (1945-1949), Uniwersytetu Warszawskiego (1949-1986), SGPiS (1949-1950) oraz IH PAN (1953-1968). Od 1986 r. członek PAN. W 1968-1970 prezes Międzynarodowego Stowarzyszenia Historii Gospodarczej.

38 Józef Chlebowczyk (1924-1985), historyk dziejów gospodarczych oraz badacz historii Śląska. Absolwent SGPiS, pracownik IH PAN oraz Instytutu Śląskiego w Katowicach. Profesor Uniwersytetu Śląskiego.

39 Andrzej Jezierski (1930-2002), historyk dziejów gospodarczych. Absolwent SGPiS. Pracownik naukowy UW.

40 Maria Ciechocińska (ur. 1934), historyk dziejów społeczno-gospodarczych i geograf. Absolwentka SGPiS. Pracownik naukowy SGPiS oraz Wyższej Szkoły Rolniczo-Pedagogicznej w Siedlcach (obecnie Uniwersytet Przyrodniczo-Humanistyczny).

41 Jerzy Ciepielewski (1927-1994), historyk dziejów gospodarczych. Pracownik naukowy Akademii Nauk Społecznych przy KC PZPR. Zajmował się polityką ekonomiczną II RP oraz relacjami gospodarczymi Polski z ZSRR w okresie międzywojennym.

42 Jerzy Jedlicki (1930-2018), historyk dziejów społeczno-gospodarczych, historyk idei. Absolwent UŁ i UW. Pracownik IH PAN, twórca i wieloletni kierownik Pracownik Dziejów Inteligencji. Działacz opozycji demokratycznej. 
większego trudu mnie przekonał. Potem ja to zreferowałem na posiedzeniu, a następnie Grodek wystąpił z krytyką mojego referatu przedstawiając tezy, które wcześniej jemu prezentowałem. No tak, profesor jest silniejszy, bo w końcu się zna na rzeczy. (śmiech) Kołłątaj oczywiście nie jest tu istotny, tylko chodzi o pewną metodę. Młody człowiek powinien zrozumieć, że możliwe są rozmaite interpretacje, dostrzec różne aspekty problemu, a nie ślepo przyjmować „jedynie słuszny” pogląd. Już parę lat później pojawił się pewien „zastępca asystenta”, który przygotowywał pracę doktorską i był biedny, gdyż co rozmowa z Grodkiem, to Grodek ma nowe pomysły, nowe koncepcje, a on stara się do nich dostosować. W końcu do mnie przyszedł, jako starszego kolegi, z prośbą o pomoc. Spróbowałem wytłumaczyć Grodkowi, że ta metoda w tym konkretnym przypadku jest absolutnie zabójcza. Niestety, przekonałem. Niestety, bo doktorant zrobił jakoś ten doktorat, ale nie był orłem i pracy na uczelni nie otrzymał, a potem na fali marca '68 wystąpił w jakimś tygodniku z krytyką pewnego tekstu Zbigniewa Landaua i mojego, „demaskując” go jako syjonistyczny. Jak mu to wydrukowali, to złożył rektorowi SGPiS razem z prośbą o przyjęcie do pracy. Rektor skądinąd był postacią nieszczególną, chociaż był wybitnym ekonomistą, lecz był też wystarczająco inteligentny, aby się zorientować, z kim ma do czynienia, i z podania o pracę nic nie wyszło. Dlatego mówię, że metoda Grodka była wprawdzie trudna i dla wielu zabójcza dosłownie, no ale jednak coś w tym było dobrego, choćby dlatego, że gdyby nie moja niefortunna interwencja, to ów jegomość by doktoratu zapewne nie zrobił i potem by nas nie straszył. Ale to było zjawiskiem częstym. Grodek podejmował dyskusje i miał pomysły w rozmaitych dziedzinach, które go interesowały, sugerował, podpowiadał. Trzeba się było jednak nad tym dobrze zastanowić, bo to wcale nie oznaczało, że opinia profesora jest rozstrzygająca. Jego można było przekonać, a poza tym on sam nie raz potrafił się przekonać, że to jednak nie jest pomysł, że to jest ślepa uliczka, że to nie to. Tak więc to było bardzo pouczające, ale nie wszyscy to wytrzymywali.

Z Grodkiem zdarzało mi się również chodzić po Tatrach. Pamiętam pierwszą wycieczkę na słowacką stronę, kiedy było to już możliwe. Było to w gronie osób z SGPiS: Andrzej Grodek z żoną, Leon Koźmiński ${ }^{43}$, wraz z synem Andrzejem ${ }^{44}$, dzisiejszym rektorem znanej uczelni, wtedy w wieku ucznia szkoły średniej. Profesor Koźmiński, popularnie określany jako Hipopotam, okazał się sympatycznym towarzyszem wędrówek, bardzo sprawnym mimo niezbyt zgrabnego zewnętrznego wyglądu. Warto dodać, że wykładał ekonomikę handlu. Natomiast jedynym handlowcem w tym gronie okazał się jego syn. Myśmy tam mieli po sakramentalne 50 koron na osobę (później tę sumę zmniejszono o połowę). Ambicją było kupić pionierki, jedyne wówczas przyzwoite obuwie do chodzenia po Tatrach. Zatem trzeba było wziąć ze sobą dozwoloną ćwiartkę spirytusu i sprzedać w Starym Smokowcu. Jedynie młody Koźmiński okazał się zdolny, by zrealizować ten interes. Bo to tak głupio było wejść do knajpy i oferować ćwiartkę spirytusu. (śmiech)

43 Leon Koźmiński (1904-1993), ekonomista, wykładowca SGH/SGPiS. Jego imieniem nazwano Wyższą Szkołę Przedsiębiorczości i Zarządzania w Warszawie.

44 Andrzej Krzysztof Koźmiński (ur. 1941), ekonomista, absolwent SGPiS oraz UW. Pracownik naukowy SGPiS i UW. Wieloletni rektor Wyższej Szkoły Przedsiębiorczości i Zarządzania. 
Więc Andrzej Grodek był pierwszym mistrzem historii gospodarczej Pana Profesora, ale potem pojawił się też Witold Kula...

Andrzej Grodek był moim pierwszym opiekunem naukowym. Jego metodę nie wszyscy wytrzymywali, bo nie była zbyt dydaktyczna. Grodek był raczej daleki od marksizmu, aczkolwiek uważał, że jest to bardzo istotny kierunek myślenia i wspierał go na niwie historii gospodarczej. Wydaje się jednak, że Witolda Kulę skierowano do nas jako pewnego rodzaju przeciwwagę. Obydwaj panowie utrzymywali bardzo poprawne stosunki. Nie wiem jak dobre, bo mogły być jakieś zakulisowe sprawy, o których zastępca asystenta, czy młodszy asystent mógł nie wiedzieć. Kula cenił i szanował Grodka, a Grodek wykorzystał Kulę, który miał z kolei inne metody wychowawcze i Kula był właśnie do dyscyplinowania młodzieży. U Witolda Kuli musieliśmy raz na miesiąc zdawać relację z lektur, które się ostatnio przeczytało. Miało to charakter kontroli. To były też pouczające, ciekawe i pożyteczne rozmowy. Z Grodkiem czasem się rozmawiało, czasem się nie rozmawiało. Poza tym on był znacznie bardziej dostępny. Spotkanie z Kulą też nie było problemem, bo podobnie jak ja mieszkał na Żoliborzu. Jednak najwięcej czasu spędzało się na uczelni. Siedziało się nie raz od rana do późnej nocy z powodu dużych obciążeń zajęciami. Ale tam była też biblioteka, również tam było Archiwum Akt Nowych, a także Biblioteka Narodowa, wobec tego to było najlepsze miejsce pracy. A Grodek mieszkał na najwyższym piętrze biblioteki uczelni, jako były jej dyrektor. Stąd kontakty były najbliższe. Gdy pierwszego była wypłata, to zwykle Chlebowczyk wpadał na pomysł, żeby zadzwonić do Grodka i zrzucić się na wino. I rzeczywiście albo Chlebowczyk, albo Kostrowicka telefonowali do niego: „Panie profesorze, my tu mamy taki problem, który warto byłoby przedyskutować...". Grodek dość łatwo dawał się namówić, przychodził. I potem mówił „Wy mnie rozpijacie!" I się tą jedną butelkę na kilka osób wypijało i gawędziło na rozmaite tematy, mniej lub bardziej naukowe. Tak więc kontakt z Grodkiem był o wiele łatwiejszy. Kula był o wiele bardziej zajęty, obciążony czasowo. Miał przecież jeszcze zajęcia na Uniwersytecie.

\section{Ale żaden z nich, ani Kula, ani Grodek nie był promotorem Pańskiego magiste- rium?}

Sprawa była dość skomplikowana. Grodek jako opiekun pracy, miał wielką zaletę: nie wtrącał się, (śmiech) ale zapytany - pomagał. Pracę magisterską pisałem o Banku Handlowym w Warszawie pod formalną opieką profesora Stanisława Rączkowskiego ${ }^{45}$, znakomitego znawcy bankowości, bo ja kończyłem kierunek „bankowość”. Nawet przez pół roku w banku pracowałem na praktyce. Rączkowski też dawał absolutną swobodę. Jako człowiek o dużym autorytecie w sferach bankowych umożliwił mi dostęp do archiwum Banku Handlowego w Warszawie, które wtedy było zamknięte. W ten sposób jako pierwszy, powiedzmy, że już historyk, miałem dostęp do bardzo ciekawego archiwum, bardzo ważnych zbiorów. To jest najlepiej zachowane archiwum bankowe w Polsce z okresu XIX w. i dwudziestolecia międzywojennego, obecnie w AAN. Właściwie Grodek bardziej mi pomagał jeśli chodzi o stronę merytoryczną, bo dobrze wiedział co jest w bibliotece. Właśnie dzięki temu, że Grodek był przed wojną dyrektorem biblioteki i był znakomitym 
znawcą bibliotekarstwa ekonomicznego, w związku z tym parę osób z katedry miało prawo chodzenia po magazynie i można było znaleźć książki, do których przez katalog trudno byłoby dotrzeć. To było niesłychanie ważne, że można w magazynie pracować.

\section{Po ukończeniu studiów magisterskich w 1954 r. trafił Pan Profesor na dwa lata do} Instytutu Nauk Społecznych przy KC PZPR.

Tak. To była bardzo ciekawa instytucja. Tam zresztą wykładał również Witold Kula. W założeniu było to miejsce, gdzie przygotowywano kadry naukowe i polityczne. Chyba nawet bardziej polityczne, gdyż większość moich koleżanek i kolegów poszła tą drogą. Ale tam byli również Jan Kancewicz ${ }^{46}$, Anna ${ }^{47}$ i Janusz Żarnowscy ${ }^{48}$, Jan Molenda ${ }^{49}$. To było bardzo ciekawe grono, które niekoniecznie pasowało do celów tejże instytucji. Wśród profesorów byli właśnie Kula, Żanna Kormanowa ${ }^{50} \ldots$ Oj! (śmiech)

\section{Czy ma Pan Profesor jakieś szczególne wspomnienia o Żannie Kormanowej?}

Ona była osobą „wierzącą”. (śmiech) A więc Partia (ona wymawiała „Parcja”), była dla niej najwyższym autorytetem. W związku z tym mogła być osobą niebezpieczną i, o ile się orientuję, bywała taka dla osób spoza Instytutu, którzy mają o niej niedobre wspomnienia. Na co dzień była upiornie nudna. Poza tym niejednokrotnie wskazywała rzeczy interesujące i niekoniecznie pasujące tego, co było wówczas powszechnie znane, ponieważ była z lat międzywojennych oczytana w literaturze wówczas nielegalnej. I to było niesłychanie pomocne i użyteczne. Na niektóre rzeczy na pewno bym nie wpadł bez jej wskazówek. Wprawdzie rezultat był taki, że jak napisałem w końcu referat, który miał być punktem wyjścia do pracy doktorskiej, to ona przeczytała, pokręciła głową i mówi: „To jest nie parcyjne, towarzyszu”. A to zapewne dlatego, że pewne koncepcje były przejęte ze studiów i artykułów niewątpliwie wybitnej postaci, jaką był Jerzy Ryng ${ }^{51}$. Ale Ryng nie przeżył czystek w ZSRR. W każdym razie pokazywał on sposób myślenia niejednokrotnie wykraczający poza obowiązujące szablony, tak więc było to bardzo ważny autor. A potem po '56 roku wróciłem do SGPiS i tam trafiłem znów do Grodka i Kuli. Tam też w 1960 r. obroniłem pracę doktorską. Kiedy się ukazała jako książka, Kormanowa była już starszą panią, na emeryturze. Spotkałem ją na ulicy (również mieszkała na Żoliborzu) i powiedziała o tej książce mniej więcej tak: „A to jest ważny wkład do marksistowskiej historiografii". Ponieważ ja się w sprawach teorii nie za bardzo orientowałem, więc nie bardzo wiem co ona tam dostrzegła z tego teoretycznego punktu

46 Jan Kancewicz (1916-2020), badacz dziejów lewicy socjalistycznej. Wnuk Maksymiliana Horwitza. Studiował historię i geografię na Uniwersytecie Moskiewskim (1934-1938). Absolwent UW (1949). Pracownik naukowy IH UW.

47 Anna Żarnowska (1931-2007), historyk dziejów społecznych i ruchu robotniczego. Absolwentka UW. Pracownik naukowy IH UW. Badaczka dziejów kobiet.

48 Janusz Żarnowski (1932-2019), historyk dziejów społecznych. Absolwent IH UW, pracownik naukowy IH PAN.

49 Jan Molenda (ur. 1930), historyk dziejów politycznych XX w.. Absolwent IH UW. Pracownik Wyższej Szkoły Nauk Społecznych przy KC PZPR oraz IH PAN.

50 Żanna Kormanowa (1900-1988), historyk ruchu robotniczego, działaczka ruchu komunistycznego. Absolwentka IH UW (uczennica Władysława Smoleńskiego), w okresie powojennym pracownik naukowy IH UW oraz Instytutu Kształcenia Kadr Naukowych przy KC PZPR.

51 Jerzy Heryng (1886-1937), działacz ruchu komunistycznego, jeden z ideologów KPP, uznany głównie pod pseudonimem „Jerzy Ryng". Ofiara wielkiej czystki, zrehabilitowany w 1955 r. W okresie PRL jego prace po raz pierwszy wydano w 1957 r. Zob. J. Ryng, Wybór pism, red. S. Bortnowska, Warszawa 1957. 
widzenia. Ale za to bardzo dobrze pamiętałem co mi na początku powiedziała. (śmiech) Tylko, że to już było po '68 roku, gdy pewne szablony przestały obowiązywać. Także mam mieszane uczucia. Ale kilka bardzo pożytecznych rzeczy mi podsunęła, niekoniecznie sobie zdając z tego sprawę. To dzięki temu właśnie, że znała literaturę publikowaną w nielegalnych wydawnictwach, które nie były znane, bo po rozwiązaniu KPP nastąpiła śmierć wielu działaczy, być może tych najbardziej twórczych, i wobec tego ich nazwiska zostały wymazane $z$ historii.

Czy wybór przez Pana Profesora historii gospodarczej był podyktowany tym, że tę dziedzinę historii można uprawiać było w miarę swobodnie?

Mnie sprawy gospodarcze po prostu interesowały. Pewne rzeczy czytałem już w dzieciństwie, a pewne rzeczy widziałem i zapamiętałem. To, co ja widziałem, nie zgadzało się z propagandą lat trzydziestych, która niejednokrotnie aż za bardzo upiększała rzeczywistość. Potem z kolei przyszła propaganda powojenna, która szła w odwrotnym kierunku, ale też nie wszystko się zgadzało. I pozostała ciekawość: jak to właściwie było? Po wojnie jednak dość szybko się można było zorientować, że jest cenzura. Na początku lat pięćdziesiątych czytaliśmy sporo rzeczy po rosyjsku. W końcu „Kapitał” czytałem po rosyjsku, bo nie było jeszcze polskiego wydania. Pierwszy tom był przetłumaczony jeszcze przed wojną, ale pozostałe tomy były tylko po rosyjsku dostępne. Bardzo jest to pouczająca lektura, zwłaszcza gdy się czyta w innym języku, dla zorientowania się w samym języku. Czytaliśmy podczas studiów tę współczesną literaturę ekonomiczną radziecką, której no... daleko było do Karola Marksa, natomiast było blisko do Josifa Wissarionowicza. W gronie bardziej wewnętrznym obliczaliśmy, ile Stalinów poszczególni autorzy cytowali na stronę. Był jakiś rekordzista, już nie pamiętam kto. Ale to trzeba było przeczytać. Było to konieczne w związku z egzaminami, ale nie miało realnego wpływu na poziom wykształcenia. Część tej literatury w języku rosyjskim była ciekawa, ale nie było jej w lekturze obowiązkowej. Podstawowa literatura do egzaminu to były takie popularne książeczki typu "biblioteka ekonomisty”, lepszych i gorszych, choć częściej gorszych autorów, trzymająca się schematów, bo inaczej być nie mogło. Z poważniejszej literatury szybko można się było zorientować, że nie warto czytać wstępu i zakończenia, bo one są dla cenzora, ewentualnie dla krytyka politycznego. Natomiast pozostała treść to sprawa już zupełnie inna, bywała często interesująca. Przy świadomości istnienia cenzury historia gospodarcza dawała pewne wolne pole. Po pierwsze dlatego, że znacznie trudniej było się cenzorowi zorientować w problematyce ekonomicznej, nieraz dość specjalistycznej. Po drugie łatwiej było pisać, zwłaszcza jeśli idzie o okres międzywojenny, który wypadał nie najlepiej. Więc wynik badań bywał nawet nieraz zgodny z "linią", jednak cenzura też się czasem wtrącała. Ale do spraw gospodarczych wtrącała się zdecydowanie rzadziej i można to było jeszcze przeboleć. Nawet nie trzeba było koniecznie dodawać Lenina i Stalina jako nieuniknionych autorów, bo ostatecznie i u Lenina, i u Stalina też można było wystarczająco dużo ciekawych rzeczy przeczytać, dotyczących właśnie tych spraw gospodarczych. Więc to było łatwiejsze.

Jakie miał Pan Profesor doświadczenia z tą dziedziną historiografii, którą wówczas nazywano historią ruchu robotniczego?

Do historii ruchu robotniczego wystarczyło przeczytać trochę broszurek wydawanych wówczas przez Zakład Historii Partii pod kierownictwem profesora Daniszewskie- 
go ${ }^{52}$, który zdaje się nie był taki głupi, jak się nam wówczas wydawało. Wprawdzie w bibliotece SGPiS można było dotrzeć do niektórych książek z okresu przed 1939 r., ale i one często nie budziły zaufania. To była literatura bez znaczenia dla poznania historii KPP. Przeczytać niewiele było można, bo nazwiska właściwie były zakazane, niemal wszystkie. Jedynie Franciszek Fiedler ${ }^{53}$, który przeżył okres czystek poza ZSRR, był cytowany. Był to jeden z nielicznych autorów politycznych, współczesnych, których warto było czytać. W rezultacie historia ruchu robotniczego stawała się dziedziną nudną. $\mathrm{Na}$ SGPiS wykładało dwóch profesorów. Jeden znakomity, Julian Hochfeld ${ }^{54}$, który o polskim ruchu robotniczym doskonale opowiadał, także z własnego doświadczenia. Natomiast historię Komunistycznej Partii ZSRR wykładał Kazimierz Owoc ${ }^{55}$, socjolog, który w swojej dziedzinie wypada całkiem dobrze, ale jako wykładowca tego przedmiotu streszczał Krótki Kurs Historii WKP(b). Wszyscy się dość szybko zorientowali i stąd Owoc nie był przez studentów szanowany. Aczkolwiek poza tym był całkiem sensownym człowiekiem, co więcej z dużym poczuciem humoru, ale ujawniał to w węższym gronie. Problematyki historii ruchu robotniczego należało więc raczej unikać. Dopiero niewiele przed '56 rokiem zaczynały się pokazywać publikacje druków wcześniej zakazanych i niedostępnych, w tym także dokumentów KPP. Były one wydawane wbrew zasadom edycji naukowych. Jedlicki był chyba pierwszy, który w druku zdemaskował „dla publiczności” edycje dokumentów KPP, wykazując, że one są preparowane, dostosowywane do bieżących potrzeb ideologicznych. To nie były zresztą ciekawe dokumenty. Jurek Jedlicki, nie wiem, dzięki jakim znajomościom, czytał te dokumenty w bibliotece Zakładu Historii Partii, gdzie to było dostępne, ale tylko dla czytelników uprawnionych. Opublikował artykuł krytykujący wartość naukową tych wszystkich wydawnictw ${ }^{56}$. I od niego się to zaczęło. Rozumiem też, że to nie była jedynie odważna decyzja Jurka, gdyż przynajmniej bez jakiejś tolerancji ze strony polityków to by się to nie mogło ukazać. Ale to pokazuje, że zmieniała się atmosfera. Ja też w Instytucie Nauk Społecznych miałem prawo do korzystania z tej biblioteki. Mnie to jednak nie interesowało, więc do tych źródeł nie sięgałem. Zatem to był początek zmian w historiografii. Wcześniej to nawet dyskusja była trudna, gdyż rzeczowe argumenty krytyczne mogły się spotkać w odpowiedzi z ideologicznymi frazesami. Pamiętam, że pierwszym odważnym był Aleksander Kochański ${ }^{57}$. Na „sławnej”

52 Tadeusz Daniszewski (1904-1969), działacz ruchu komunistycznego, historyk i publicysta. Kierownik Wydziału Historii Partii KC PZPR (1948-1957), dyrektor Zakładu Historii Partii przy KC PZPR (1957-1968).

53 Franciszek Fiedler (1880-1956), historyk ruchu robotniczego i działacz komunistyczny. Studiował na uniwersytetach w Berlinie i Zurychu. Publicysta i ideolog ruchu komunistycznego. W okresie powojennym wykładowca w Centralnej Szkole PPR i na Uniwersytecie Warszawskim. Członek PAN.

54 Julian Hochfeld (1911-1966), socjolog, absolwent Uniwersytetu Jagiellońskiego. Działał w organizacjach lewicowych. Profesor SGPiS, UW i Zakładu Filozofii PAN. W 1957-1959 był dyrektorem Polskiego Instytutu Spraw Międzynarodowych. W latach 1962-1966 był wicedyrektorem Departamentu Nauk Społecznych w UNESCO w Paryżu.

55 Kazimierz Owoc (1914-1961), ekonomista, oficer Wojska Polskiego. Absolwent Uniwersytetu Jana Kazimierza we Lwowie. W okresie powojennym wykładał w Wyższej Szkole Oficerów Politycznych w Rembertowie. Po przejściu do rezerwy w 1949 r. pracował w SGPiS, w 1952-1954 był prorektorem tej uczelni.

56 Jerzy Jedlicki napisał artykuł podważający autentyczność publikacji źródłowych wydawanych przez ZHP KC PZPR, który nie został opublikowany, był jednak szeroko komentowany. Wspomniany tekst, a także informacje o okolicznościach niedoszłej publikacji, opublikował Dominik Czapigo w magazynie „Karta”; zob. J. Jedlicki, Przegrana partia, „Karta” 2018, nr 97, s. 112-121.

57 Aleksander Kochański (1928-2019), historyk, badacz dziejów lewicy. Absolwent IH UW. Pracownik Zakładu Historii Partii przy KC PZPR oraz Centralnego Archiwum przy KC PZPR. Redaktor kwartalnika „Z Pola Walki” oraz periodyku "Archiwum Ruchu Robotniczego". 
konferencji otwockiej Kochański był jedynym studentem, który odważył się zabrać głos. Nieważne już, co powiedział, bo rozumiem, że nie mógł się wychylić za bardzo, ale to był właśnie ten, który się odważył w gronie autorytetów. Kochański później też należał do historyków, którzy zabrali się na serio do historii ruchu robotniczego w granicach możliwości istniejących przy działaniu cenzury. Można się było wychylić, ale nie za daleko. Tak więc od '56 roku sytuacja się zaczyna poprawiać. Również w 1956 r. nastąpiła likwidacja Instytutu Nauk Społecznych i ci, którzy mieli iść do polityki, poszli do polityki, a pozostali, którzy zapewne zostali ocenieni, że nie nadają się do polityki, mieli możliwość powrotu tam, gdzie pracowali poprzednio.

Po ‘56 roku możemy też zaobserwować, że wielu historyków, którzy się w latach powojennych historią gospodarczą zajmowali, zaczynają od tego odchodzić.

To już jest okres, gdy powstawały możliwości dyskusji, ale to nie było ucieczką od historii gospodarczej. Przeciwnie, to i dla historii gospodarczej stwarzało większe możliwości. Już w swej książce o Grabskim wprowadzam odwołania do autorów, którzy 2-3 lata wcześniej byliby nie do cytowania. To już jest po prostu nowy okres. Kto miał zainteresowania sięgające bliższe kultury, socjologii, jak np. Jerzy Jedlicki, który był pod wpływem Witolda Kuli, mógł się tym zająć. Także to nie historia gospodarcza została wyparta przez nowe, inne zagadnienia, ile po prostu rozszerzały się możliwości badawcze na różne inne sfery, zagadnienia. Jurek Jedlicki wywołał kiedyś duże zaskoczenie. Napisał świetną część do III tomu Historii Polski PAN-owskiej, rozdziały dotyczące historii kultury; kultury muzycznej między innymi. Nie to żeby Jurek się muzyką nie interesował, ale nie przejawiał wcześniej zainteresowań z punktu widzenia pisarskiego. A rozdział ten okazał się bardzo ciekawym fragmentem tego tomu. Także zainteresowania rozwijały się i różnicowały, kontakty w wielu przypadkach się utrzymywały. Mieliśmy kontakt z Kulą i tworzyliśmy pewne grono: Wanda Reykowska ${ }^{58}$, Jerzy Jedlicki, Wacław Długoborski ${ }^{59}$, Tadeusz Łepkowski ${ }^{60}$, Elżbieta Kaczyńska ${ }^{61}$, Stenia Kowalska ${ }^{62}$, Andrzej Jezierski - który, niestety, wkrótce zajął się polityką, a to był naprawdę dobry historyk. Kula dbał o to, by się z nami spotykać, mniej lub bardziej systematycznie. Kierunki zainteresowań zaczęły się rozchodzić, np. ja zostałem przy dwudziestoleciu międzywojennym, Ela Kaczyńska zajęła się XIX w., chociaż pewnym momencie zbliżyły nas zagadnienia drobnomieszczaństwa. Wanda Reykowska określała to grono „Kulkami”. Odbywaliśmy co pewien czas dyskusje nad nowymi pracami.

58 Wanda Reykowska-Łukaszewicz (ur. 1931), historyk dziejów gospodarczych, ekonomistka. Absolwentka UW. Pracownik naukowy Wydziału Nauk Ekonomicznych UW.

59 Wacław Długoborski (ur. 1926), historyk dziejów gospodarczych. Absolwent Uniwersytetu Wrocławskiego. Pracownik naukowy Uniwersytetu Śląskiego. Długoborski pod kierunkiem Witolda Kuli obronił doktorat na Uniwersytecie Warszawskim.

60 Taduesz Łepkowski (1927-1989), historyk dziejów XIX w., varsavianista, badacz historii krajów Ameryki Południowej. Absolwent IH UW. Profesor IH PAN, w którym zorganizował Zakład Dziejów Ameryki, Afryki i Azji, którego był także pierwszym kierownikiem.

61 Elżbieta Kaczyńska (ur. 1934), historyk dziejów gospodarczych i społecznych. Absolwentka IH UW. Pracownik naukowy UW oraz Wyższej Szkoły Informatyki i Ekonomii TWP w Olsztynie. Autorka pionierskich prac z dziedziny historii więziennictwa.

62 Stefania Kowalska-Glikman (1926-2015), historyk dziejów społecznych XIX i XX w. Pracownik naukowy IH PAN. Prowadziła badania nad dziejami polskiego mieszczaństwa, zajmowała się również metodologią historii. 
Jak ocenia Pan Profesor znaczenie marksizmu dla historii gospodarczej?

Ja się na metodologii nie znam i z góry się od tego odżegnuję. Główna zaleta wprowadzenia marksizmu polegała na tym, że sprawy ekonomiczne i historia gospodarcza zaczęły nabierać znaczenia. Wcześniej były traktowane marginesowo, bo to nie jest towar chodliwy z punktu widzenia szerszego kręgu czytelników, a więc mało interesujący wydawców, którzy muszą utrzymać wydawnictwa. Wtedy natomiast stał się towarem modnym, wspieranym finansowo, między innymi przez polityków. Myślę, że współcześnie nie mógłbym wraz ze Zbigniewem Landauem napisać i opublikować wielu prac dlatego, że by nie było chętnych wydawców. Publikacja książek jest kosztowna, a zwłaszcza książek z zakresu historii gospodarczej z reguły o małym nakładzie, tym bardziej, że wchodzi w grę statystyka, wykresy, tabele. W tym redakcja, a nawet autorzy się potrafią zgubić. Wiem z własnego doświadczenia. Nasz Zarys historii gospodarczej Polski międzywojennej ukazał się w kilku wydaniach. W jednym z nich, drugim czy trzecim, znalazła się tablica, prawdziwa, owszem, ale pod błędnym tytułem. To wynikło przez jakiś przypadek. Potem byli recenzenci, bardziej i mniej krytyczni. Jednak wpadłem na to sam, dopiero gdy chciałem wziąć dane statystyczne z tej książki do czegoś innego. Widzę, że to jest nonsens, że to się nie zgadza. Okazało się, że wszystko się zgadza, tylko inny powinien być tytuł, gdyż inna jest zawartość tabeli. Nastąpiło to $w$ trakcie prac redakcyjnych, przy jakichś przeformatowaniach. Nawet najbardziej nam nieprzychylni krytycy tego nie zauważyli, chociaż to była jedyna rzeczywiście wielka gafa w tej książce. Późniejsze wydania są już oczywiście poprawne. W każdym razie historiografia gospodarcza nie jest na rynku towarem chodliwym. Wówczas to finansowała „Książka i Wiedza”, która jako wydawnictwo partyjne miała redakcję gospodarczą. Sprawy współczesne gospodarki były bardziej skomplikowane, a historia była, jak mi się wydaje, dziedziną dość pewną politycznie. Wydawnictwo przyjmowało prace do druku, na co dostawało jakieś pieniądze w charakterze dotacji. W każdym razie mieli środki na sfinansowanie wydania i zapłacenie honorarium autorom. I to było całkiem przyzwoite honorarium. Chociaż roboty było dużo, to rzeczywiście był to dochód, który miał znaczenie, zwłaszcza jeżeli to była gruba książka. (śmiech) Także historia gospodarcza utrzymywała się z trzech powodów. Po pierwsze istniał krąg zainteresowanych autorów. Po drugie były zainteresowane wydawnictwa. Po trzecie, jeżeli nawet zgodność z pewnymi wymaganiami teoretycznymi nie była tak bardzo ścisła, to jednak ten kierunek pozostawał przynajmniej formalnie zgodny z preferowaną ideologią. Natomiast z mojego punktu widzenia pisałem o tym, co mnie interesuje, nie musiałem zastanawiać się, czy jest to zgodne z jakaś ideologią, czy nie Choć zdarzały się ingerencje cenzury także w książkach i artykułach z zakresu historii gospodarczej.

Czy jednak takie prace, jak Problemy i metody historii gospodarczej ${ }^{63}$ Witolda Kuli miały dla Pana Profesora znaczenie?

To jest kapitalna książka. Pouczająca przez sposób myślenia. Nie sądzę jednak, by pan znalazł jakieś bezpośrednie odniesienia do niej w tym co z Landauem pisałem. Może dlatego, że to zupełnie inny okres. Sądzę jednak, że to miało znaczenie. Czytałem ją z dużym zainteresowaniem podobnie jak inne książki Kuli. To po prostu kwestie, które mnie intere- 
sowały. A ponieważ zajmowałem się historią gospodarczą, siłą rzeczy na pewno to miało jakiś wpływ na to, co pisałem.

Po '56 roku otworzyły się szerzej granice zachodnie i zaczęły się ożywione kontakty z nauką francuską. Dla polskiej historiografii gospodarczej miało to duże znaczenie. Wystarczy wspomnieć o bliskich relacjach naukowych Witolda Kuli czy Mariana Małowista ${ }^{64}$ z Fernandem Braudelem ${ }^{65}$ oraz gronem jego współpracowników i uczniów. Czy Pan Profesor miał również jakieś doświadczenia na tym obszarze?

To oczywiście było bardzo ważne, ale mnie bezpośrednio nie dotyczyło. Ja francuskiego nie znam, zacząłem się wprawdzie uczyć, ale osiągnąłem tylko tyle, że mogę czytać, zrozumiem to, co jest mi potrzebne, zwłaszcza w dziedzinach które mnie interesują. Raz udało mi się jednak porozumieć z jednym Francuzem - ale po czesku. (śmiech) Obydwaj zajmowaliśmy się sprawami czechosłowackimi. Także to nie był mój krąg. Już wtedy zaczynałem odchodzić w stronę Europy Środkowej. Kiedy się zaczęły otwierać granice, to na SGPiS-ie mieliśmy kontakty z Pragą, Bratysławą i Berlinem. W Berlinie był Institut für Wirtschaftsgeschichte Jürgena Kuczynskiego ${ }^{66}$ i to były łatwe wyjazdy. Konferencje można było organizować bez problemu, bo uczelnie na to znajdowały pieniądze. Był też łatwy dostęp do literatury, do źródeł, co w pewnym stopniu określało kierunki zainteresowań. Historiografia NRD-owska była ciekawa i ważna, tyle że gospodarcza, gdzie Kuczynski trzymał parasol nad swoimi uczniami i nad gronem osób, które z nim współpracowały. On miał rzeczywiście dość dużą, względną swobodę wypowiedzi. A z sąsiadami południowymi było jeszcze łatwiej. Język był w miarę wspólny. Jednak z wyjazdami było gorzej, bo na to były potrzebne pieniądze.

\section{A kontakty naukowe ze Związkiem Radzieckim?}

Do ZSRR nie było łatwo się dostać. Kiedyś nawet próbowałem, ale na szczęście się nie udało, wyjechać do Moskwy na studia doktoranckie. Podejrzewam, że dlatego, iż napisałem, co myślę o ministerstwie resortowym, a jeszcze gorzej, że to opublikowałem. Sądzę, że było to istotną przeszkodą. Ale w każdym razie nie było łatwo uzyskać zgody na wyjazd w tamtym kierunku. To się zaczęło zmieniać o wiele później.

\section{Więc na Zachód w ogóle Pan Profesor w tamtych czasach nie wyjeżdżał?}

Na Zachód dopiero chyba 1970 r. i to dzięki temu, że zaproponowano mi współpracę w jednym wydawnictwie angielskim, w obszernym, dużym przedsięwzięciu o gospodarce Europy Środkowej i udało mi się wyjechać na dwa tygodnie i tam poznałem historyków z Czechosłowacji, którzy uniknęli „bratniej pomocy”.

Marian Małowist (1909-1988), historyk dziejów gospodarczych. Absolwent UW przedstawiciel szkoły Marcelego Handelsmana. Pracownik naukowy IH UW oraz IH PAN. Twórca szkoły historycznej.

65 Fernand Braudel (1902-1985), francuski historyk, czołowy przedstawiciel drugiego pokolenia szkoły „Annales”, twórca koncepcji „historii totalnej”. Jego prace oraz dorobek organizacyjny wywarły ogromny wpływ na rozwój nauki historycznej i socjologii w XX w.

66 Jürgen Kuczynski (1904-1997), niemiecki historyk gospodarczy, działacz ruchu komunistycznego. Pracował na Uniwersytecie w Berlinie, a także w Niemieckiej Akademii Nauk. Zorganizował i kierował Instytutem Historii Gospodarczej (Institut für Wirtschaftsgeschichte). 


\section{A jak było z kontaktami z naszymi południowymi sąsiadami?}

Dużo wyjeżdżałem do Pragi, Bratysławy, Sofii... A jak to się zaczęło? Sprawa była prosta. Dość wcześnie, gdy jeszcze Biblioteka Narodowa i Archiwum Akt Nowych były na Mokotowie, siedziało się cały dzień w AAN-ie, bibliotekach. W jakiejś przerwie wyszedłem do szatni, pospacerować, odpocząć chwilę. Zaczepił mnie jakiś jegomość i tak mi się jego język polski wydawał nieco dziwny, że pomyślałem: „Może przyjechał ze Stanów Zjednoczonych?" Okazało się że to był Jaroslav Valenta ${ }^{67}$, historyk z Pragi, z którym się zaprzyjaźniłem. Valenta, jako człowiek przedsiębiorczy, dość często pojawiał się w Warszawie, więc były okazje żeby sobie pogadać. Potem z tego zespołu przyjechał do nas na krótki pobyt Zdeněk Sládek ${ }^{68}$. Świetny historyk, zajmujący się Związkiem Radzieckim, trzeba dodać, że z powodzeniem, mimo rozmaitych kłopotów. Niestety obaj już nie żyją. Do grona czeskich przyjaciół dołączył jeszcze Václav Prúcha ${ }^{69}$, praski historyk gospodarczy, a z Bratysławy Jožo Faltus $^{70}$ (także nie żyje). Więc z jednej strony były to kontakty na niwie ekonomii, z uczelniami ekonomicznymi w Pradze i Bratysławie, ale też kontakty z zespołem, w którym byli Valenta i Sládek. Stąd myśmy zaczęli z Landauem trochę zajmować się gospodarką całego regionu, ze szczególnym uwzględnieniem sąsiadów. To nieraz robiliśmy też dla potrzeb dyskusyjnych. A poza tym, proszę pana, jak długo można się zajmować dziejami gospodarczymi dwudziestu lat? No więc razem ze Zbyszkiem doszliśmy do wniosku, że jeszcze należałoby napisać libretto do opery i będzie komplet. Zbyszek poszedł bardziej w kierunku dziejów finansów, czego ja też nie zarzuciłem. Ja jednak poszedłem bardziej w kierunku naszych sąsiadów i tu już trzeba było wkroczyć w sferę zagadnień stosunków międzynarodowych. Na tym zresztą dobrze znał się Józef Chlebowczyk. Wprawdzie przez jakiś czas pracował w Karwinie, skąd zresztą pochodził, ale miałem z nim nieustannie kontakt, zwłaszcza gdy został prorektorem filii Uniwersytetu Śląskiego w Cieszynie Niestety, i on nie żyje.

\section{Sporo też miejsca w swojej twórczości naukowe dotyczącej krajów Europy Środ- kowej poświęcił Pan Profesor Bułgarii...}

A Bułgaria to w gruncie rzeczy jest wina Mariana Turskiego, redaktora działu historycznego „Polityki”. Potrzebne mu były jakieś artykuły o historii krajów socjalistycznych i dość, że mnie namówił na Bułgarię. Język bułgarski nie jest tak bardzo skomplikowany, pod warunkiem że się pamięta, że nie jest to rosyjski, bo to się może poplątać. A kraj jest ciekawy, historia interesująca. Za czasów Żiwkowa był świetny okres dla historiografii, nie zawsze w pełni zgodniej z obowiązującą ideologią. Wydawano bardzo dużo prac poważnych, naukowych, choć nie dla szerszego kręgu czytelników. Gdzieś około lat siedemdziesiątych, gdy mówiłem już jako tako po bułgarsku, pojawił się jakiś historyk z Zakładu Historii Partii

67 Jaroslav Valenta (1930-2004), czeski historyk, badacz relacji polsko-czeskich. Wspólnie z Jerzym Tomaszewskim napisał artykuł Polska wobec Czechosłowacji w 1933 roku, „Przegląd Historyczny” t. 70, 1979, z. 4, s. 695721.

68 Zdeněk Sládek (1926-2003), czeski historyk, badacz relacji czechosłowacko-sowieckich, zajmował się także historią gospodarczą. Zawodowo związany z Uniwersytetem Karola w Pradze.

69 Václav Prúcha (ur. 1931), czeski historyk zajmujący się dziejami gospodarczymi XX w. Profesor Wyższej Szkoły Ekonomicznej w Pradze. Zob. V. Prucha, Rozwój gospodarczy Czechosłowacki w latach 1945-1991, tłum. P. Godlewski, Kutno 2006.

70 Jožo Faltus (1929-1999), słowacki historyk, badacz dziejów gospodarczych, historii Niemiec i relacji czechosłowacko-niemieckich. Profesor Uniwersytetu Ekonomicznego w Bratysławie. 
w Sofii. Pisałem akurat dla jednego z naszych czasopism przegląd najnowszych publikacji bułgarskich. Zwróciłem szczególną uwagę na młodego historyka, który znacznie odbiegał od szablonów i w swoich artykułach pokazywał nowe perspektywy, pisał przeobrażeniach systemu ustrojowego Bułgarii międzywojennej. Więc chwalę go w rozmowie z moim rozmówcą z Sofii. I dostrzegam na jego twarzy wyraźne niezadowolenie. W końcu mówi On prawi samo greszki... („On robi same błędy...”). Podjąłem polemikę, że tylko ten, co nic nie robi, nie robi błędów. Widać było, że to młode pokolenie już zupełnie nie pasowało do poprzedniej generacji dogmatyków. Iłczo Dymitrow później był, niestety, ministrem oświaty - bardzo nacjonalistycznym, ale to już było wiele lat później.

\section{Czy zajmowanie się historią Czechosłowacji w kontekście wydarzeń Praskiej Wio- sny było bezpieczne?}

Nie było. Konkretnie trudno mi powiedzieć, bo nie pasjonuję się Instytutem Pamięci Narodowej. Naprawdę nie ciekawi mnie, co tam mogę znaleźć. Ale w jednej ich publikacji znalazłem dokument, jak to jeden z kolegów informował służbowego rozmówcę, że wraz z innym moim przyjacielem (działo się to wiosną '68 roku) wysłaliśmy wspólny list do znajomych w Pradze. To była nieprawda, bo żadnych wspólnych listów do nikogo nie wysyłałem, nawet z przyjaciółmi. Nie widziałem takiej potrzeby. Po drugie, informator nie mógłby o tym wiedzieć, no chyba, że siedział na poczcie i czytał cudze listy. Także jakieś zainteresowanie było na pewno. Moje kontakty z Pragą były dość żywe. W 1967 r. byłem tam, a niezależnie od tego pobytu już wtedy miałem te kontakty ze środowiskiem Sládka i Valenty. Wtedy ukazała się świetna książka Sládka na temat historii Związku Radzieckiego w okresie międzywojennym. Przeszła przez cenzurę! Była nowa, oryginalna. Oczywiście autor musiał się podporządkować pewnym wymaganiom. Były też inne ciekawe pozycje, które się ukazywały. Druga połowa lat sześćdziesiątych to zupełnie nowy okres w literaturze historycznej tego kraju. Věra Olivová71 opublikowała w 1968 r. Československo v rozrušené Evropě, później została przetłumaczona na język angielski72. Takich pozycji było o wiele więcej. Wystarczy wziąć „Slovanský přehled"73. Gdzieś od 1966 r. wyraźnie się zmienia charakter tego pisma, staje się coraz ciekawsze. Artykuły o poszczególnych krajach demokracji ludowej stanowiły z punktu widzenia czytelnika polskiego nowy powiew w literaturze historycznej. Stąd też stosunkowa łatwość naszych kontaktów w Pradze i w Bratysławie, bo chociaż w pewnych sprawach historycznych się różniliśmy, to jednak było wiele rzeczy dla nas nowych i cennych. W maju, czerwcu chyba próbowano mnie zachęcić, zdaje się że nie bez wiedzy jakichś zainteresowanych organów, abym tłumaczył różne czeskie teksty na polski celem wydania. Ponieważ o moim rozmówcy w gruncie rzeczy nic nie wiedziałem, to powiedziałem „Nie, proszę pana” i użyłem jakiegoś ładnego określenia na temat „druków zakazanych”. Niedługo później ostrzegł mnie Jezierski, że się mną interesują, ponieważ otrzymuję za dużo czasopism czeskich i słowackich.

71 Věra Olivová (1926-2015), czeska historyczka zajmująca się dziejami Czechosłowacki, głównie I Republiki. Pracowała na Uniwersytecie Karola w Pradze.

72 V. Olivová, The doomed democracy: Czechoslovakia in disrupted Europe 1914-1938, tłum. G. Theiner, Montreal 1972.

73 „Slovanský přehled”, czeski miesięcznik naukowy publikujący artykuły dotyczące dziejów i kultury państw słowiańskich. Został założony w 1898 r. przez Adolfa Černego. 


\section{Istotny dla SB mógł być również kontakt Pana Profesora z Ledererem ${ }^{74}$ ?}

Nie jest wykluczone, że mój kontakt z Ledererem mógł zostać odnotowany. Dziś to u nas zapomniana postać, jednak w 1968 r. odegrał ważną i pozytywną rolę. Jiří Lederer to był świetny historyk, dziennikarz. Rok sobie przestudiował w Polsce po '56 roku i się zaraził - jeśli można tak powiedzieć. Potem wielokrotnie bywał w Polsce, miał liczne kontakty. Ja go poznałem w 1967 r., gdzieś w gronie znajomych. Gawędziliśmy sobie na dowolnie wybrane tematy. Potem dopiero dowiedziałem się, kto to jest. W 1968 r. zaczął pisać świetne reportaże o Polsce, krytyczne, o tym co się dzieje, o fali antysemityzmu etc. Przyjaciele mi przysyłali dość długo prasę tygodniową, czasem codzienną, co tam akurat było najciekawsze. Lederer stał się u nas jednym z głównych celów ataków prasowych. Potem stracił pracę, przesiedział się $w$ więzieniu, w konsekwencji wyjechał za granicę, gdzie zmarł. A to co pisał było bardzo ciekawe: rzeczowe, kompetentne. Widać było, że zna rzeczywistość polską bardzo dobrze, nie tylko z jakiejś lektury i jakichś kontaktów.

\section{Czy wówczas, wokół wydarzeń 1968 r., narastało zainteresowanie cenzury twór- czością dotyczącą Czechosłowacji?}

Oczywiście. To zainteresowanie było. Jeden z moich przyjaciół, Jerzy Ciepielewski, który pracował w szkole partyjnej, potrzebował dla potrzeb swojej uczelni zbioru artykułów o historii krajów socjalistycznych po II wojnie światowej. Namówił mnie, żebym napisał coś o Czechosłowacji i o Bułgarii. Rzeczywiście napisałem. I to poszło w powielonej wersji bez kłopotu. Ale potem Ciepielewski wpadł na racjonalny pomysł, żeby wydać to drukiem jako książkę. Słusznie, rzeczywiście niczego takiego na rynku księgarskim nie było. Artykuły były różnej wartości, bo to zależało od tego, kto pisał. No i ja miałem pewne kłopoty. Po pierwsze napisałem o konsekwencjach tzw. kultu jednostki w Bułgarii. I to się cenzurze nie spodobało. Na szczęście akurat ukazała się w Sofii książka o historii Komunistycznej Partii Bułgarii. Napisana była dość solidnie, bez owijania w bawełnę. Wobec tego dałem cytat z tej książki. To mi zakwestionowano, tłumacząc, że Bułgarom wolno pisać, ale my nie możemy. Ale już wiedziałem, że książka ukazała się w przekładzie rosyjskim, wobec tego powiedziałem „Jest przekład rosyjski” - „A to proszę mi pokazać”. Poszedłem do biblioteki, wypożyczyłem, przyniosłem, pokazałem, że jest po rosyjsku to samo, i poszło bez zmian. Tak załatwiłem Bułgarię. Z Czechosłowacją było o wiele trudniej. Przecież nie mogłem napisać, że na prośbę polityków czechosłowackich udzielano bratniej pomocy, etc. Wobec tego pozostała formułka, z którą do dziś bym się zgodził, że - po opisaniu sytuacji narastania kryzysu wewnętrznego - w tych warunkach nieuniknione stało się, że ZSRR i kraje socjalistyczne zdecydowały się interweniować. Cenzurze się to nie podobało, bo przecież było zaproszenie..., że tak nie można. Uratował mnie dyrektor Instytutu Marksizmu-Leninizmu w Bratysławie, świetny zresztą historyk, Viliam Plevza ${ }^{75}$. Miałem jego nową książkę, gdzie użył podobnego sformułowania. Wobec tego udowodniłem, że to napisał dyrektor IM-L w Bratysławie, a cenzura zgodziła się na to samo po polsku, bez żad"drugiego obiegu". Zob. J. Lederer, Czeskie rozmowy, tłum. A. Rajski, K. Śniegocka [pseud. Haliny Kuligowskiej i Joanny Goszczyńskiej], Warszawa 1987.

75 Viliam Plevza (ur. 1934), czechosłowacki historyk ruchu robotniczego, działacz komunistyczny. Był dyrektorem Instytutu Marksizmu-Leninizmu KC Komunistycznej Partii Słowacji. Był także wykładowcą Uniwersytetu Karola w Pradze. 
nych frazesów. Okazało się, że zrobiłem jeszcze jeden błąd, gdyż w przypisie cytowałem artykuł Jiřího Hájka, redaktora organu partii komunistycznej „Rudé Právo”76. Zapomniałem, że takie samo nazwisko miał minister spraw zagranicznych Czechosłowacji, który w lecie 1968 r. wystąpił w ONZ-cie z protestem przeciwko interwencji. Ponieważ artykuł mój był na pograniczu cenzury, uznałem, że dobrze się powołać na jakiś artykuł redaktora „Rudégo Práva”, a to był tekst, który mi akurat pasował. Ale pani cenzor kręci głową. Wtedy mi nagle błysnęło, że przecież nazwiska się zgadzają. „Tak proszę pani, Hájek, ale to nie ten Hájek, ten jest redaktorem „Rudégo Práva”. Ja mogę napisać, że to nie ten, ale czy to wypadnie dobrze...?" Poszło! Ale to była już zabawa z cenzurą.

Mówiąc już serio. To, co pisało się o krajach sąsiednich, w większym stopniu zwracało uwagę cenzorów. Lepsza była sytuacja z Bułgarią, bo w naszej cenzurze zupełnie się nie orientowano, i wobec tego można się było wykręcić całkiem dobrze. Gorzej było z Czechosłowacją, gdyż wymagało to szukania sformułowań, które mieściły się w tym, co cenzor może puścić, a zarazem tak, żeby nie było jednoznaczną akceptację tego, co podaje się w wersji oficjalnej. To się robiła gimnastyka. Ciekawe, że to nie dotyczyło recenzji. To był akurat okres, kiedy współpracowałem z Januszem Żarnowskim, który wówczas redagował „Studia z Dziejów ZSRR i Europy Środkowej”77 (teraz tytuł nieco zmieniono). Tam zamieszczałem systematycznie recenzje z publikacji dotyczących Czechosłowacji wydawanych na Zachodzie. Niektóre z książek emigracyjnych jakimś cudem do mnie docierały. Kto z przyjaciół mi to załatwił, to tego ja nie wiem. Ale faktem jest że przychodziły do mnie pod różnymi okładkami, np. francuskiego czasopisma psychologicznego, a kogo obchodzi psychologia? (śmiech) A w środku było co innego. No więc pisałem z tego wszystkiego recenzje, gdyż wiedziałem, że w Pradze i Bratysławie tego oficjalnie nie będą mieli w ręku. U nas można o tym było napisać, a oni czasopisma polskie dostawali. Tego nasza cenzura nie usuwała i potem miałem wiadomości od przyjaciół, że czytali. Tam te pozycje w nieoficjalnym obiegu nieraz krążyły, ale trzeba było przynajmniej wiedzieć, że się ukazały. Także to dawało jakiś pożytek i tu nie było przypadku żadnej ingerencji. Natomiast ingerencja była w innym przypadku, radzieckim. Mianowicie ktoś z przyjaciół przesłał mi antysemicką książeczkę wydaną w Kijowie. Napisałem bardzo ideologiczną recenzję wychodzącą od koncepcji marksizmu i leninizmu w kwestii narodowej, dowodząc, że książeczka jest absolutnie antymarksistowska. Tego cenzura nie tylko nie puściła, ale nawet nie puściła tytułu. Jedyny znany mi przypadek, że nawet tytuł okazał się niestrawny. Ślad po tym zachował się w „Przeglądzie Historycznym”. Także czytelnik nawet nie wiedział, jaka to książka została skrytykowana. To też zresztą pokazuje zakres ingerencji.

W kolejnych latach z dużym powodzeniem zajmował się Pan Profesor mniejszościami narodowymi. Dwie książki Rzeczpospolita wielu narodów i Ojczyzna nie tylko Polaków były popularne.

Tak. To książki niemal równolegle napisane. Z Rzeczpospolitą wielu narodów było tak, że w redakcji tygodnika „Fołks Sztyme”78, któremu po 1968 r. brakowało autorów, pu-

78 „Fołks Sztyme”, żydowskie czasopismo ukazujące się od 1946 r. jako dziennik, a od 1968 do 1991 jako tygodnik. 
blikowałem jakieś dokumenty obrazujące sytuację Żydów polskich w czasach III Rzeszy. A potem prosili mnie o jakieś inne teksty i napisałem kilka takich artykulików na temat mniejszości narodowych w Polsce międzywojennej. Potem ktoś, już nie pamiętam kto, powiedział, że przecież z tego książka by wyszła. Wobec tego zaproponowałem wydawnictwu „Czytelnik", taką książkę. W „Czytelniku” zastanawiali się nad tym bardzo długo, w końcu zgodzili się i ostatecznie to się ukazało w 1985 r.. Zanim jednak "Czytelnik" się zdecydował, to samo zaproponowała mi Młodzieżowa Agencja Wydawnicza. Czekając jeszcze na odpowiedź z „Czytelnika”, nie mogłem dać im od razu odpowiedzi. Kiedy przyszła odpowiedź pozytywna, wybrałem „Czytelnika”. Co wobec tego zrobić Młodzieżową Agencją Wydawniczą? Coś innego, ale na ten sam temat. Obie książki ukazały się mniej więcej w tym samym czasie. Z tym, że Rzeczpospolita wielu narodów się rozeszła, a Ojczyzna nie tylko Polaków dość szybko też zniknęła z księgarń. A że komuś z jakichś względów chciałem posłać jeden egzemplarz Ojczyzny..., poszedłem do firmowej księgarni MAW i zażądałem tę książkę. Obiecali mi sprowadzić. Po paru dniach otrzymałem informację, że nakład książki jest już wyczerpany. Minęło parę lat, Młodzieżowa Agencja Wydawnicza przestała istnieć. Pozostał lokal, piwnice. Ktoś przejmował ten lokal po nich. Otrzymuję telefon, że mają w piwnicach 10000 egzemplarzy mojej książki i szkoda im oddać na makulaturę, może ja bym przyjechał i wziął. Miałem, owszem, samochód, ale tyle tysięcy książek raczej bym nie przewiózł, a poza tym straciłem już zainteresowanie. Także poszło na makulaturę. Okazało się, że niemal cały nakład został wycofany. Dlaczego? Już nawet tego nie ma od kogo się dowiedzieć. Coś się musiało nie podobać, ale nie wiem co.

\section{Przy tym nie było już problemów z cenzurą?}

W „Czytelniku” przeszło bez ingerencji cenzury. Ale był wtedy precedens w „Fołks Sztyme". Wprawdzie to tygodnik żydowski, ale jednak już było drukowane.

Ostatnią niezwykle ważną dziedziną badań Pana Profesora to historia Żydów. Pewne wątki da się zaobserwować już we wczesnej Pana twórczości. Jakie są źródła tej pasji?

Nie można uprawiać historii gospodarczej Polski bez historii Żydów. Pisanie historii gospodarczej w kategorii Judenrein jest nonsensem. Tu nie chodzi o domniemany wielki kapitał żydowski. Tu chodzi o te miliony drobnych producentów, handlarzy. W znacznej części międzywojennej Polski nie byłoby handlu, gdyby nie kupcy żydowscy. Także historia gospodarcza zmuszała wręcz do zajęcia się tą problematyką. Podjąłem takie zadanie, które się w końcu okazało nie do zrealizowania z powodu braku czasu: żeby zacząć czytać po żydowsku. Od biedy mogę teraz czytać. Podjąłem kiedyś próbę przetłumaczenia jednego artykułu z czasopisma żydowskiego. W końcu nie przetłumaczyłem, ale rozumiałem na tyle, że mogłem się do niego odwoływać. To są po prostu rzeczy absolutnie niezbędne.

Jaka jest opinia Pana Profesora na temat miejsca, jakie autorzy polscy przyznają tematyce dziejów Żydów polskich w syntezach, wydawnictwach przekrojowych, podręcznikach?

Wygląda to bardzo różnie. Ostatnio pisałem w „Przeglądzie Historycznym” recenzję jednego z przekrojowych wydawnictw historii Polski, takiego popularnego zarysu dziejów, 
czegoś w rodzaju repetytorium przed maturami. To klasyczny przykład skandalu wydawniczego, gdzie mniejszość narodowe znalazły się na absolutnym marginesie. Dobrze że w ogóle są gdzieś tam wspomniane.

\section{Ten problem dotyczy chyba nie tylko problematyki Żydów, ale wszystkich mniej- szości?}

Z mniejszościami były zawsze kłopoty, w dużym stopniu polityczne. Rozumiem doskonale, że trudno było na serio pisać na tematy ukraińskie, kiedy Ukraińcy występowali tylko w roli Hajdamaków, UPA i temu podobnych przypadkach. Trudno było pisać, gdyż można było pisać niemal jedynie w stylu Edwarda Prusa ${ }^{79}$, same najgorsze wyrazy po kilka razy na stronę, a na serio się nie dawało. Pozostawało milczeć, albo przemycać tylko marginesowo.

\section{Wróćmy jednak do tematyki żydowskiej. W okresie PRL-u można było bezpiecznie uprawiać tę dziedzinę?}

O sprawach żydowskich też nie było łatwo pisać. To nie było zakazane, ale określiłbym, że nie zawsze było dobrze widziane. „Biuletyn Żydowskiego Instytutu Historycznego” był taką oazą, a właściwie klatką, do której sprawy żydowskie zostały zamknięte. A poza tym nic. W sprawach gospodarczych było trochę łatwiej. Już w 1968 r. stało się to jednak trudne. W podręczniku do historii gospodarczej Polski XIX i XX w., w kolejnym wydaniu, cenzura wycięła nam cały fragment na temat antysemityzmu gospodarczego. Nie był to duży fragment. W kolejnych wydaniach to poszło bez problemu. Więc były takie wahania: lepiej - gorzej. Ten kto się tym specjalnie nie interesował dochodził do wniosku: „A po co ja mam się w ten niejasny interes pakować? Lepiej trzymać się z dala." (śmiech) 1956 r. też stał się takim lepszym sezonem, ale to tylko taka chwila i nic więcej. Więc nic dziwnego, że w syntezach dziejów Polski wydanych za PRL o sprawach żydowskich nie było albo nic, albo prawie nic. Pionierem był Henryk Zielińskiº i jego książka o Polsce międzywojennej ${ }^{81}$. Dużo rzeczy mu opowiedziałem, on to wprowadził i to przeszło. To oczywiście była jego inicjatywa. Ta praca się ukazała już, niestety, po jego śmierci. Zieliński zachęcony dobrymi recenzjami (jeszcze przed wydaniem) wprowadził do swojego rozdziału w IV tomie PAN-owskiej Historii Polski82, pewne tematy żydowskie. Między innymi był pierwszy, który napisał o pogromie we Lwowie. Wcześniej opublikowałem tylko źródła. Niestety, tekst Zielińskiego ukazał się w całości tylko w materiałach do dyskusji, czyli w tzw. makiecie. Ostateczna wersja się chyba nie ukazała. Zieliński jednak to zrobił i jeżeli to się nawet poza makietę nie wydostało, to było ważne. Potem ukazała się jego książka o Polsce międzywojennej, i to w pewnym sensie ułatwiło życie wszystkim następcom. Powolutku problematyka żydowska zaczynała wkraczać do opracowań historycznych. Tylko dochodzi problem także językowy. Można pisać o sprawach żydowskich bez znajomości oryginalnych źródeł

79 Edward Prus (1931-2007), historyk, politolog. Był pracownikiem naukowym m.in. Wyższej Szkoły Pedagogicznej TWP. Autor kontrowersyjnych opracowań dotyczących relacji polsko-ukraińskich.

80 Henryk Zieliński (1920-1981), historyk dziejów najnowszych. Absolwent Uniwersytetu Jagiellońskiego. Pracownik naukowy Uniwersytetu Wrocławskiego i Uniwersytetu Śląskiego w Katowicach.

81 Zob. H. Zieliński, Historia Polski 1914-1939, Wrocław 1983.

82 Zob. Historia Polski, t. 4, 1918-1939, cz. 1, 1918-1926, rozdz. 1-13 (1918-1921), red. L. Grosfeld, H. Zieliński, Warszawa 1969. 
żydowskich, jednak jest to trudne. Coraz więcej historyków w Polsce na szczęście potrafi czytać w oryginale źródła żydowskie. Ale źródła polskie też są wystarczająco duże. Wymaga to jednak wielu poszukiwań, często bardzo trudnych, co zniechęca.

Uczeni uprawiający tę dziedzinę bywają też różnie odbierani w środowisku czy w społeczeństwie, prawda?

Tak. Problematyka żydowska od razu stwarza pewne problemy, w stylu: „A kim pan właściwie jest?" Dokuczyłem kiedyś Normanowi Daviesowi, gdy w którymś z pierwszych numerów tygodnika "Solidarność" pod redakcją Tadeusza Mazowieckiego zamieścił artykuł, gdzie pochwalił mnie w sposób dość dwuznaczny, że tylko ktoś spośród mniejszości może o mniejszościach tak pisać. Napisałem list do redakcji, który wydrukowali bez problemu, chyba nie dlatego, że Mazowieckiego znałem wcześniej. Zatytułowałem to, o ile dobrze pamiętam „Pochodzenie istotne jest dla jamnika, nie dla historyka” czy coś w tym rodzaju. Dlatego, że często pojawiają się pytania. Ja już z tego powodu byłem Żydem, Ukraińcem, podejrzewano mnie - i byłem nawet przesłuchiwany w Pałacu Mostowskich w tej sprawie - że jestem Białorusinem. Pan profesor Czubiński ${ }^{83}$, z którym byłem na stopie wojennej, gdy z pełnym przekonaniem pochwaliłem jakiś jego artykuł dotyczący spraw niemieckich za oryginalność ujęcia, chociaż wiedziałem, że się śmiertelnie obrazi za pochwałę, a nawet gorzej, że się poczuje zagrożony, napisał artykuł, jakiś komentarz, gdzie nie podał wprawdzie nazwiska, jednak wyraźnie sugerował, że ja jestem agentem wywiadu zachodnioniemieckiego w Polsce. To było czytelne, pewien przyjaciel poinformował mnie o tym artykule i zareagował na to. Ja nie zareagowałem. Pisanie na tego rodzaju tematy od razu wywołuje podejrzenia. To jest argument, który dla niektórych osób może odgrywać rolę. Mnie jest obojętne, jak mnie kto określi. Mogę występować nawet jako Chińczyk jeśli komuś się to podoba. A rzeczywiście mogę wystąpić także jako Japończyk, gdyż jakiś mój artykuł został przetłumaczony na japoński. (śmiech)

\section{Dziękuję za rozmowę.}

\section{Bibliografia}

\section{Źródła archiwalne}

Archiwum Akt Nowych, Ministerstwo Edukacji Narodowej, Akta Jerzego Tomaszewskiego. Archiwum Akt Nowych, Archiwum Szkół Partyjnych, Akta Aspiranckie Jerzego Tomaszewskiego.

Archiwum Instytutu Historii Polskiej Akademii Nauk, Akta Bronisława Geremka. Archiwum Uniwersytetu Warszawskiego, Akta Jerzego Tomaszewskiego.

83 Antoni Czubiński (1928-2003), historyk dziejów XX w. Absolwent Uniwersytetu im. Adama Mickiewicza w Poznaniu. Pracownik naukowy UAM. Działacz PZPR, w 1971-1974 prorektor Wyższej Szkoły Nauk Społecznych przy KC PZPR. 


\section{Źródła drukowane}

Jedlicki J., Przegrana partia, „Karta” 2018, nr 97, s. 112-121.

Tomaszewski J., Odpowiedzi na niektóre pytania zadane lub niezadane, jak też na rozmaite domysły lub wymysły, życzliwe, a także miej lub bardziej nieżyczliwe, lub zrodzone z bezinteresownej ciekawości, „Midrasz” 2013, z. 5, s. 54-66.

\section{Literatura przedmiotu}

Bibliografia Jerzego Tomaszewskiego za lata 1953-2000, [w:] Rozdział wspólnej historii. Studia z dziejów Żydów w Polsce ofiarowane Jerzemu Tomaszewskiemu w siedemdziesiątą rocznicę urodzin, red. J. Żyndul, Warszawa 2001 s. 15-70.

Chojnowski A., Tomaszewski J., Izrael, Warszawa 2001.

Ciepielewski J., Kostrowicka I., Landau Z., Tomaszewski J., Historia gospodarcza świata XIX i XX wieku, Warszawa 1970.

Historia Europy, red. A. Mączak, Wrocław 1997.

Koseski A., Ważniewski W., recenzja: M. Turlejska, Zapis..., „Z Pola Walki” 1973, z. 2-3, s. 359-365.

Landau Z., Tomaszewski J., Lata interwencjonalizmu państwowego 1936-1939, Warszawa 1989.

Landau Z., Tomaszewski J., Od Grabskiego do Piłsudskiego: okres kryzysu poinflacyjnego i ożywienia koniunktury 1924-1929, Warszawa 1971.

Landau Z., Tomaszewski J., W dobie inflacji 1918-1923, Warszawa 1967.

Landau Z., Tomaszewski J., Wielki kryzys 1930-1935, Warszawa 1982.

Landau Z., Tomaszewski J., Zarys historii gospodarczej Polski 1918-1939, Warszawa 1960. Landau-Czajka A., Jerzy Tomaszewski (8 X 1930 - 4 XI 2014), "Kwartalnik Historyczny” 2015, z. 1, s. 216-219.

Markowski A., Prof. Jerzy Tomaszewski (1930-2014), „Dzieje Najnowsze” 2015, z. 2, s. 239-241.

Mity i fakty. Z prof. Jerzym Tomaszewskim na temat Kresów Wschodnich $w$ latach 19181939 - rozmawia Piotr Łuczka, „Nurt” 1984, z. 4, s. 4-6; z. 5, s. 8-11.

Narody i polityka. Studia ofiarowane profesorowi Jerzemu Tomaszewskiemu, red. A. Grabski, A. Markowski, Warszawa 2010.

Tomaszewski J., Preludium Zagłady. Wygnanie Żydów polskich z Niemiec w 1938 roku, Warszawa 1998.

Tomaszewski J., Bułgaria 1944-1971. Trudna droga do socjalizmu, Warszawa 1989.

Tomaszewski J., Czechy i Słowacja, Warszawa 2006.

Tomaszewski J., List do redakcji, „Z Pola Walki” 1981, z. 2, s. 261-264.

Tomaszewski J., Mniejszości narodowe w Polsce XX wieku, Warszawa 1991.

Tomaszewski J., Ojczyzna nie tylko Polaków. Mniejszości narodowe w Polsce w latach 1918-1939, Warszawa 1985.

Tomaszewski J., Republika Czeska 1918-2013, Warszawa 2014.

Tomaszewski J., Rozwój Bułgarii w latach 1944-1956, Warszawa 1980.

Tomaszewski J., Rzeczypospolita wielu narodów, Warszawa 1985.

Tomaszewski J., Stabilizacja waluty w Polsce. Z badań nad polityką gospodarczą rządu polskiego przed przewrotem majowym, Warszawa 1961. 
Tomaszewski J., Z dziejów Polesia 1921-1939. Zarys stosunków społeczno-ekonomicznych, Warszawa 1963.

Tomaszewski J., Zarys dziejów Żydów w Polsce w latach 1918-1939, Warszawa 1990.

Tomaszewski J., Żydzi w II Rzeczypospolitej, oprac. A. Markowski, S. Rudnicki, Warszawa 2016.

Turlejska M., Zapis pierwszej dekady 1945-1954, Warszawa 1972.

Żyndul J., Jerzy Tomaszewski - in memoriam, „Kwartalnik Historii Żydów” 2015, z. 1, s. $187-190$.

dr Tomasz Siewierski, historyk, adiunkt w Instytucie Historii Nauki im. L. i A. Birkenmajerów PAN. Zajmuje się dziejami nauki w XX w. ze szczególnym uwzględnieniem historii historiografii i politycznych uwarunkowań działalności uczonych po $1945 \mathrm{r}$.

e-mail: tsiewierski@gmail.com

Data zgłoszenia artykułu: 2 lutego 2020

Data przyjęcia do druku: 31 maja 2020 